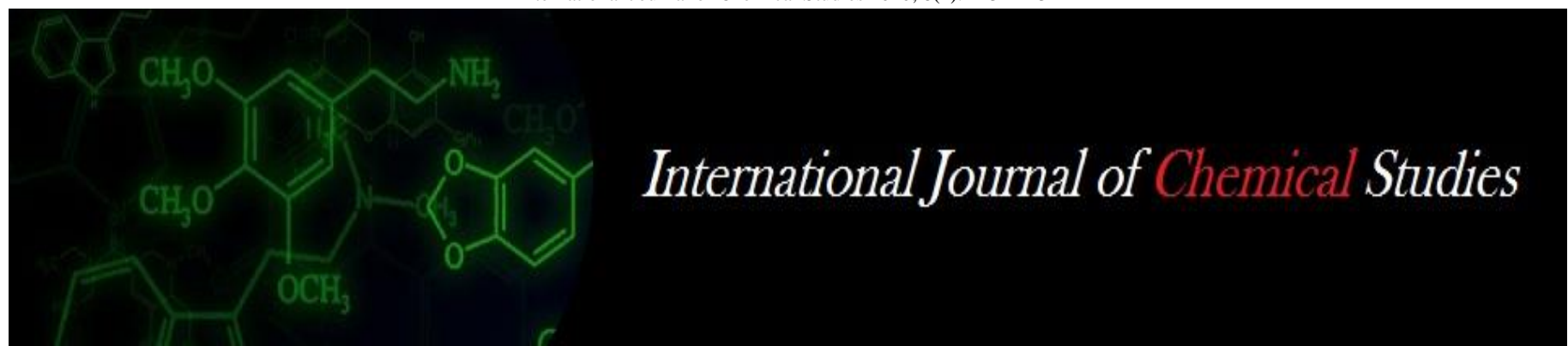

P-ISSN: 2349-8528

E-ISSN: 2321-4902

IJCS 2020; 8(1): 2131-2134

(C) 2020 IJCS

Received: 19-11-2019

Accepted: 21-12-2019

Nistha Rawat

Ph.D. Scholar, Department of Entomology, G.B.P.U.A. \& T.

Pantnagar, Uttarakhand, India

\section{AK Karnatak}

Professor, Department of

Entomology, G.B.P.U.A. \& T.,

Pantnagar, Uttarakhand, India

RM Srivastava

Professor, Department of

Entomology, G.B.P.U.A. \& T.,

Pantnagar, Uttarakhand, India
Corresponding Author:

Nistha Rawat

Ph.D. Scholar, Department of

Entomology, G.B.P.U.A. \& T.,

Pantnagar, Uttarakhand, India

\section{Population dynamics of okra shoot and fruit borer (Earias vittella) of okra in agro-climatic condition of Pantnagar}

\author{
Nistha Rawat, AK Karnatak and RM Srivastava
}

DOI: $\underline{\text { https://doi.org/10.22271/chemi.2020.v8.i1af.8584 }}$

\begin{abstract}
The present investigation was carried out to study the population dynamics of Okra shoot and fruit borer (Earias vittella) and influence of various weather parameters on them at Vegetable research centre, Gobind Ballabh Pant University of Agriculture \& Technology, Pantnagar, Uttarakhand, during 20162017. The incidence of Okra shoot and fruit borer was recorded at $28^{\text {th }}$ SMW (standard meteorological week) to $39^{\text {th }} \mathrm{SMW}$. The result revealed that peak incidence of Okra shoot and fruit borer population was observed 5.9 larvae/ plant in $37^{\text {th }}$ standard meteorological week. Correlation of Okra shoot and fruit borer (Earias vittella) population with weather parameters revealed that there was non-significant negative correlation with Minimum temperature $(r=-0.162)$, evening relative humidity $(r=-0.545)$ and sunshine hour $(\mathrm{r}=-0.572)$ while significant negative correlation with rainfall $(\mathrm{r}=-0.610 *)$. While maximum temperature $(r=0.513)$, morning relative humidity $(r=-0.201)$ and wind velocity $(r=-0.411)$ showed nonsignificant positive correlation. The linear regression analysis using weather parameters as independent variables and Okra shoot and fruit borer as dependent variables could explain the variability up to $78 \%$ $\left(R^{2}=0.76\right)$, respectively.
\end{abstract}

Keywords: Okra, okra shoot and fruit borer, population

\section{Introduction}

Vegetables are the substantial part of human diet. Vegetables contain almost all nutritional requirements that our body needs. The health benefits of vegetable nutrition are enormous. They are the affluent and cheaper source of vitamins, minerals, antioxidants, dietary fibers and trace elements. As vegetables contain these health benefitting phyto-chemical compounds, they not only protect the human body from oxidant stress, diseases, and cancers, but also help our body in developing the capacity to fight against these diseases by boosting its immunity.

Among the divergent group of vegetables, Okra Abelmoschus esculentus L. (Moench) is the second largest cultivated crop, a potential export earner and accounting for about 60 percent of export of the total fresh vegetables (Peirce, 1987) ${ }^{[13]}$. India is the second largest producer of vegetables in the world after China, while it ranks first in Okra production which is $61.9 \%$ of the total global production followed by Nigeria (22.2\% of the total global production). In India, production was about 6073 thousand MT from 506 thousand ha of area during 20172018 (Anonymous, 2018) ${ }^{[1]}$.

In India, major leading state in Okra production is Andhra Pradesh. It has production of around 1184.2 thousand tons followed by West Bengal (862.1 thousand tons) and Bihar (788.3 thousand tons) (Anonymous, 2018) ${ }^{[1]}$. Uttakhand's share in total okra production is about $3 \%$. It is grown in almost all the districts of Uttrakhand. Amongst them, Dehradun is the major okra producing district followed by Udham Singh Nagar, Pithoragarh, Tehri, Nainital, Haridwar and Chamoli.

Among the biotic factors insect-pests are predominant and occur regularly at different stages of crop growth. Among other various factors responsible for lower yield of Okra, insect pests viz., the fruit borer, Helicoverpa armigera (Hubner), Okra shoot and fruit borer, Earias vittella (Fabricius) and sucking insect pests viz., whitefly Bemesia tabaci (Gennadius)., Jassids, Amrasca biguttulla biguttula (Ishida) and thrips Thrips tabaci (Lind) are highly destructive causing serious damage and are responsible for lowering the yield of Okra crop (Lal et al., 1990) ${ }^{[9]}$. 
The important limiting factor in the successful cultivation of Okra is the damage caused by insect-pests, mainly fruit borers and sucking insects. The important species of fruit borers are Earias vittella (Fabricius) (Krishnaiah et al.1980 ${ }^{[8]}$, Rawat and Sahu, $1973^{[15]}$ ), E. insulana (Bioduval) (Tripathi and Singh, 1990) ${ }^{[20]}$, and Helicoverpa armigera (Hubner) (Rawat and Sahu, 1973) ${ }^{[15]}$. The larvae of Okra shoot and fruit borer, E. vittella (Fab.) are the major constraint in maximizing production in summer grown okra. Damage due to the borer pests in summer season has been reported to range from 4.65 to $17.15 \%$ (Dhamdhre et al., 1984) ${ }^{\text {[4] }}$. It causes up to $41.60 \%$ cop loss in different parts of India (Srinivasan and Krishnakumar, 1988) ${ }^{[19]}$. However, according to Hiremath and Thontadarya (1984) ${ }^{[5]}$ the damage caused by Earias spp. may reach as high as $60.68 \%$. Besides the fruits, it also damages growing shoots which adversely affects the overall health of plants and yield

In the light of above facts this experiment was carried out to determination of population dynamics of okra shoot and fruit borer and impact of weathers parameters on them.

\section{Material and method \\ Experimental site}

The field experiments were carried out to observe the population dynamics and correlation of weather parameter with Okra shoot and fruit borer (Earias spp) of Okra crop (variety Parbhani Kranti) at Vegetable Research centre (VRC), G. B. Pant University of Agriculture and Technology, Pantnagar Udham Singh Nagar (Uttarakhand) during kharif crop season 2017. Observations on population of pests were recorded after 15 days of sowing (15 DAS) at weekly interval up to harvesting. These observations of number of lavae per plant, from five randomly selected plants per plot selected leaving border rows. The mean weekly weather data during crop season was collected from meteorological observatory, N.E. Borlaug Crop Research Centre, Pantnagar.

\section{Fruit borers percent infestation}

The observation on healthy and the infested Shoots/Fruits the percentage of infested fruit on number basis. The presence of hole/holes was the criteria for separating damaged fruits from healthy ones. The percentage of infestation was calculated by the following formula as adopted by Karmakar et al. (2007) [7].

Percent infestation $=\frac{\text { Infested fruit } / \text { shoot }}{\text { Infested fruit } / \text { shoot }+ \text { Healthy fruit } / \text { shoot }} \times 100$

\section{Results and Discussion \\ Population dynamics and fluctuation in population of Okra shoot and fruit borers, Earias vittella Fab of Okra during kharif, 2017}

In kharif, 2017 the pooled incidence of Earias spp. was observed from $28^{\text {th }}$ standard metrological week (SMW) to $39^{\text {th }}$ standard metrological week (SMW) (Table 1). The pest marked its first appearance by average of 2.1 larvae/plant at $32^{\text {nd }}$ standard metrological week (SMW) when the maximumminimum temperature, morning-evening relative humidity $(\mathrm{RH})$, rainfall, sunshine hrs, wind velocity were $33.0{ }^{\circ} \mathrm{C}, 26.3$ ${ }^{0} \mathrm{C}, \quad 89 \%$ (0712am), $70 \%$ (1412pm), 040.2mm, 06.8hrs, $5.7 \mathrm{~km} / \mathrm{hr}$, respectively. The population gradually increased and attained maximum (5.9 larvae/plant) in the $37^{\text {th }}$ standard metrological week (SMW) when the maximum-minimum temperature, morning-evening relative humidity (RH), rainfall, sunshine hrs, wind velocity were $32.1{ }^{0} \mathrm{C}, 24.5{ }^{\circ} \mathrm{C}$,
$89 \%$ (0712am), 71\% (1412pm), $059.4 \mathrm{~mm}, 04.3 \mathrm{hrs}, 4.5$ $\mathrm{km} / \mathrm{hr}$ respectively followed by gradual decrease in population till $39^{\text {th }}$ standard metrological week (SMW) (Fig 4.3). So the ecological parameters prevailed during $37^{\text {th }}$ standard metrological week (SMW) appeared to be congineal for this pest.

Data presented in Table 1. revealed that the larval population of Okra shoot and fruit borer appeared from second metrological week of August (32 ${ }^{\text {nd }}$ standard metrological week) to last week of September $\left(39^{\text {th }}\right.$ standard metrological week). However, the maximum population of the pest was recorded in $37^{\text {th }}$ standard metrological week. These observations are close to study of Bajad et al. (2014) ${ }^{[3]}$ their observation was that Earias vittella incidence were from $34^{\text {th }}$ standard metrological week (i.e fourth week of August) on five week old crop and continued till $43^{\text {rd }}$ standard metrological week and peak population was observed in $38^{\text {th }}$ standard metrological week (63 DAS), followed by a marked decline in population. While Sharma et al. (2010) ${ }^{[16]}$ in Rajasthan, observed that the first infestation of Earias vittella started in $29^{\text {th }}$ standard week while peak infestation of plants $(91.6 \%)$ by Earias vittella occurred during $45^{\text {th }}$ (112 DAS) standard metrological week. Also the maximum number of larvae (7.5 larvae/10 plants) was recorded in the 42th standard metrological week (91 DAS). The present finding are also supported by Meena et al. (2010) ${ }^{[11]}$ studied the activity of Earias vittella in Rajasthan from the beginning of August till harvesting also peak population was observed in $3^{\text {rd }}$ week of October. Padwal et al., (2015) ${ }^{[13]}$ reported the population of Earias vittella on Okra commenced on the mid of August i.e. $33^{\text {rd }}$ standard metrological week followed by a gradual increase in population till the first week of October $\left(40^{\text {th }}\right.$ standard metrological week). Yadvendu (2001) ${ }^{[21]}$ reported that pest population attained its peak in first and fourth week of September.

\section{Per cent shoot and fruit infestation by Earias spp}

The per cent infestation of shoot and fruit by Earias spp in kharif, 2017 was observed highest in $37^{\text {th }}$ standard metrological week (Table $2 \&$ Table 3 ). Thus the second week of September was found to be the most favourable period for infestation on shoot and fruit(31.0 and 39.83) when the maximum-minimum temperature, morning-evening relative humidity $(\mathrm{RH})$, rainfall, sunshine hrs, wind velocity were $32.1{ }^{\circ} \mathrm{C}, 24.5^{\circ} \mathrm{C}, 89 \%$ (0712am), $71 \%$ (1412pm), 059.4 $\mathrm{mm}, 04.3 \mathrm{hrs}, 4.5 \mathrm{~km} / \mathrm{hr}$ respectively.

\section{Correlation between population dynamics of Okra shoot and fruit borers, Earias vittella of Okra with weather parameters (2014)}

Simple correlation worked out between the weather parameters and larval population of Earias vittella Table. 1 revealed that there was non-significant negative correlation with Minimum temperature $(r=-0.162)$, evening relative humidity $(r=-0.545)$ and and sunshine hour $(r=-0.572)$ while significant negative correlation with rainfall $\left(\mathrm{r}=-0.610^{*}\right)$. While maximum temperature $(\mathrm{r}=0.513)$, morning relative humidity $(\mathrm{r}=-0.201)$ and wind velocity $(\mathrm{r}=-0.411)$ showed non-significant positive correlation. These studies indicating that the Earias vittella population increased with increasing maximum temperature $(\mathrm{r}=0.513)$, morning relative humidity $(\mathrm{r}=-0.201)$ and wind velocity $(\mathrm{r}=-0.411)$ while decreased by increasing Minimum temperature $(\mathrm{r}=-0.162)$, evening relative humidity $(\mathrm{r}=-0.545)$ and and sunshine hour $(\mathrm{r}=-$ $0.572)$ and rainfall $(r=-0.610 *)$. The result found was similar 
to the study of Dhamdhere et al., (1984) ${ }^{[4]}$ who also observed a negative correlation between Okra shoot and fruit borer population and relative humidity. Aziz et al., (2011) [2] studied the fluctuations of fruit and shoot infestation (Earias spp.) with the abiotic factors during 2006 and 2007 and found that the infestation of fruit and shoot borer was negatively correlated with the relative humidity and rainfall also significantly positively correlated with temperature this observation is similer to our observation. Sharma et al. (2010) [16] also found that fruit and shoot borer infestation was negatively correlated with the relative humidity and rainfall. Laichattiwar et al. (2014) ${ }^{[10]}$ observed that fruit and shoot borer infestation showed a negative correlation with relative humidity also non-significant with temperature and rainfall. Sardana and Kumar (1989) [17] also showed positive correlation with this pest and temperature. Radke and Undirwade (1981) [14] also reported higher incidence of Earias $s p$ with increasing temperature whereas Kadam and Khaire (1995) ${ }^{[6]}$ reported significantly negative correlation between the incidence of fruit and shoot borer and relative humidity.

\section{Correlation of weather parameters with per cent shoot and fruit infestation}

The impact of weather factor on the present shoot infestation caused by Earias spp. on Okra during kharif, 2017 is presented in Table 2. The result revealed that there was significantly negative correlation with wind velocity and nonsignificant negative correlation with maximum temperature while minimum temperature, with relative humidity, rainfall and sun-shine hours showed a non-significant positive correlation with fruit infestation by shoot and fruit borer.

While the impact of weather factor on shoot caused Earias spp. on Okra during kharif, 2017 is presented in Table 3. It revealed that there was non-significantly negative correlation of shoot infestation with maximum temperature and minimum temperature while showed a non- significant positive correlation of relative humidity, rainfall, sun-shine hours with fruit infestation by shoot and fruit borer and significantly negative correlation with wind velocity.
Following regression equation was developed to predict the incidence of Okra shoot and fruit borers, Earias vittella

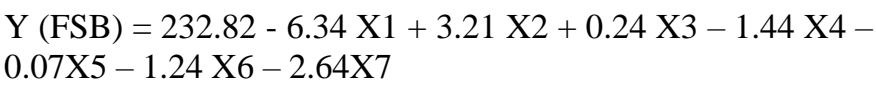

The regression equation revealed that the various abiotic factors were found to be most influencing factors which contributed $\mathrm{R}^{2}=0.76(76 \%)$ variation in Okra shoot and fruit borers, Earias vittella

The regression equation was fitted to the study the effectiveness of weather parameters indicated that for every 1 ${ }^{0} \mathrm{C}$ decrease in maximum temperature 6.34 number of borers increased while increase in $1{ }^{\circ} \mathrm{C}$ in minimum temperature 3.21 number of borers increased. While $1{ }^{0} \mathrm{C}$ increase in morning relative humidity 0.24 number of borers increased. Whereas, $1{ }^{0} \mathrm{C}$ decrease in evening relative humidity, rainfall, sunshine hours and wind velocity decrease in 1.44, 0.07, 1.24 and 2.64 number of borers, respectively.

\section{Conclusion}

Okra is one of the succeeding cultivated crop in India. This central crop is infested by various insects pests but among them okra shoot and fruit borer cause severe damage resulting in lowering the yield of crop. It has been from $28^{\text {th }}$ standard metrological week (SMW) to $39^{\text {th }}$ standard metrological week (SMW). The population gradually increased and attained maximum (5.9 larvae/plant) in the $37^{\text {th }}$ standard metrological week (SMW). Simple correlation worked out between the weather parameters and larval population of Earias vittella revealed that there was non-significant negative correlation with Minimum temperature $(\mathrm{r}=-0.162)$, evening relative humidity $(r=-0.545)$ and and sunshine hour $(r=-0.572)$ while significant negative correlation with rainfall $\left(\mathrm{r}=-0.610^{*}\right)$. While maximum temperature $(\mathrm{r}=0.513)$, morning relative humidity $(\mathrm{r}=-0.201)$ and wind velocity $(\mathrm{r}=-0.411)$ showed non-significant positive correlationVariations in insect population viz., borer $77 \%\left(\mathrm{R}^{2}=0.77\right)$. Hence it can be concluded that this insect population were greatly influenced by weather parameters.

Table 1: Fluctuation in population of Okra shoot and fruit borer in relation to weather parameters at VRC, Pantnagar, during Kharif, 2017

\begin{tabular}{|c|c|c|c|c|c|c|c|c|c|c|}
\hline \multirow{2}{*}{ Month } & \multirow{2}{*}{ Date } & \multirow{2}{*}{ SMW } & \multicolumn{2}{|c|}{ Temperature $\left({ }^{0} \mathrm{C}\right)$} & \multicolumn{2}{|c|}{ Relative Humidity (\%) } & \multirow{2}{*}{ Rainfall (mm) } & \multirow{2}{*}{ Sun-Shine Hrs. } & \multirow{2}{*}{$\begin{array}{c}\text { Wind Velocity } \\
(\mathrm{km} / \mathrm{hr} .)\end{array}$} & \multirow{2}{*}{$\begin{array}{c}\text { FSB } \\
\text { population/plant }\end{array}$} \\
\hline & & & Max. & Min. & 0712 am & $1412 \mathrm{pm}$ & & & & \\
\hline July & $09-15$ & 28 & 33.0 & 26.2 & 89 & 72 & 052.6 & 05.6 & 4.2 & 0 \\
\hline July & $16-22$ & 29 & 32.0 & 25.5 & 91 & 76 & 119.2 & 05.9 & 2.8 & 0 \\
\hline July & $23-29$ & 30 & 30.8 & 24.9 & 89 & 76 & 125.9 & 06.5 & 3.9 & 0 \\
\hline July-Aug & $30-05$ & 31 & 31.7 & 25.7 & 86 & 69 & 150.8 & 07.1 & 5.5 & 0 \\
\hline Aug & 06-12 & 32 & 33.0 & 26.3 & 89 & 70 & 040.2 & 06.8 & 5.7 & 2.1 \\
\hline Aug & $13-19$ & 33 & 32.9 & 25.9 & 93 & 69 & 100.6 & 03.9 & 4.7 & 4.6 \\
\hline Aug & $20-26$ & 34 & 33.1 & 26.3 & 87 & 67 & 002.4 & 04.7 & 7.8 & 4.8 \\
\hline Aug-Sept & $27-02$ & 35 & 34.0 & 25.5 & 89 & 65 & 026.6 & 03.8 & 5.5 & 4.5 \\
\hline Sept & 03-09 & 36 & 32.7 & 25.3 & 91 & 68 & 002.4 & 06.2 & 6.2 & 4.9 \\
\hline Sept & $10-16$ & 37 & 32.1 & 24.5 & 89 & 71 & 059.4 & 04.3 & 4.5 & 5.9 \\
\hline Sept & $17-23$ & 38 & 32.7 & 24.2 & 90 & 66 & 076.6 & 03.6 & 5.9 & 3.9 \\
\hline Sept & $24-30$ & 39 & 32.6 & 23.2 & 87 & 62 & 003.4 & 02.9 & 8.9 & 2.5 \\
\hline \multicolumn{3}{|c|}{ Correlation } & $0.513^{\mathrm{NS}}$ & $-0.162^{\mathrm{NS}}$ & $0.201^{\mathrm{NS}}$ & $-0.545^{\mathrm{NS}}$ & $-0.610^{*}$ & $-0.572^{\mathrm{NS}}$ & $0.411^{\mathrm{NS}}$ & - \\
\hline \multicolumn{3}{|c|}{$\mathrm{R}^{2}$ (Regression Coefficient) } & 0.76 & & & & & & & \\
\hline
\end{tabular}

* Significant at 0.01 level; ** Significant at 0.05 level; Max- Maximum temperature; Min. - Minimum temperature; FSB- Fruit and shoot borer Regression Equation:-

FSB: $\mathrm{Y}=232.82-6.34 \mathrm{X} 1+3.21 \mathrm{X} 2+0.24 \mathrm{X} 3-1.44 \mathrm{X} 4-0.07 \mathrm{X} 5-1.24 \mathrm{X} 6-2.64 \mathrm{X} 7$

Where, $\mathrm{X}_{1}=$ Maximum Temperature, $\mathrm{X}_{2}=$ Minimum Temperature, $\mathrm{X}_{3}=$ Relative Humidity (Morning), $\mathrm{X}_{4}=$ Relative Humidity (Evening), $\mathrm{X}_{5}=$ Rainfall, $X_{6}=$ Sun-Shine Hours, $X_{7}=$ Wind velocity 
Table 2: Per cent fruit infestation by shoot and fruit borer in relation to weather parameters at VRC, Pantnagar, during kharif, 2017

\begin{tabular}{|c|c|c|c|c|c|c|c|c|c|c|}
\hline \multirow{2}{*}{ Month } & \multirow{2}{*}{ Date } & \multirow{2}{*}{ SMW } & \multicolumn{4}{|c|}{ Temperature $\left({ }^{\circ} \mathrm{C}\right)$ Relative Humidity (\%) } & \multirow{2}{*}{ Rainfall (mm) } & \multirow{2}{*}{ Sun- Shine Hrs } & \multirow{2}{*}{$\begin{array}{c}\text { Wind Velocity } \\
(\mathrm{km} / \mathrm{hr})\end{array}$} & \multirow{2}{*}{$\begin{array}{c}\text { Fruit Infestation } \\
(\%)\end{array}$} \\
\hline & & & Max. & Min. & 0712 am & $1412 \mathrm{pm}$ & & & & \\
\hline Aug & $20-26$ & 34 & 33.1 & 26.3 & 87 & 67 & 002.4 & 04.7 & 7.8 & 21.25 \\
\hline Aug-Sept & $27-02$ & 35 & 34.0 & 25.5 & 89 & 65 & 026.6 & 03.8 & 5.5 & 30.12 \\
\hline Sept & 03-09 & 36 & 32.7 & 25.3 & 91 & 68 & 002.4 & 06.2 & 6.2 & 32.51 \\
\hline Sept & $10-16$ & 37 & 32.1 & 24.5 & 89 & 71 & 059.4 & 04.3 & 4.5 & 39.83 \\
\hline Sept & $17-23$ & 38 & 32.7 & 24.2 & 90 & 66 & 076.6 & 03.6 & 5.9 & 29.05 \\
\hline Sept & $24-30$ & 39 & 32.6 & 23.2 & 87 & 62 & 003.4 & 02.9 & 8.9 & 20.16 \\
\hline \multicolumn{3}{|c|}{ Correlation Fruit infestation (\%) } & $-0.301^{N S}$ & $0.045^{\mathrm{Ns}}$ & $0.682^{\mathrm{Ns}}$ & $0.797^{\mathrm{Ns}}$ & $0.561^{\mathrm{Ns}}$ & $0.367^{\mathrm{NS}}$ & $-0.937^{*}$ & \\
\hline
\end{tabular}

Table 3: Per cent shoot infestation by shoot and fruit borer in relation to weather parameters at VRC, Pantnagar, during kharif, 2017

\begin{tabular}{|c|c|c|c|c|c|c|c|c|c|c|}
\hline \multirow{2}{*}{ Month } & \multirow{2}{*}{ Date } & \multirow{2}{*}{ SMW } & \multicolumn{4}{|c|}{ Temperature $\left({ }^{0} \mathrm{C}\right)$ Relative Humidity (\%) } & \multirow{2}{*}{ Rainfall (mm) } & \multirow{2}{*}{ Sun- Shine Hrs. } & \multirow{2}{*}{$\begin{array}{c}\text { Wind Velocity } \\
(\mathbf{k m} / \mathbf{h r} .)\end{array}$} & \multirow{2}{*}{$\begin{array}{c}\text { Shoot infestation } \\
(\%)\end{array}$} \\
\hline & & & Max. & Min. & 0712 am & $1412 \mathrm{pm}$ & & & & \\
\hline Aug & $20-26$ & 34 & 33.1 & 26.3 & 87 & 67 & 002.4 & 04.7 & 7.8 & 17.35 \\
\hline Aug-Sept & $27-02$ & 35 & 34.0 & 25.5 & 89 & 65 & 026.6 & 03.8 & 5.5 & 24.7 \\
\hline Sept & 03-09 & 36 & 32.7 & 25.3 & 91 & 68 & 002.4 & 06.2 & 6.2 & 27.05 \\
\hline Sept & $10-16$ & 37 & 32.1 & 24.5 & 89 & 71 & 059.4 & 04.3 & 4.5 & 31.0 \\
\hline Sept & $17-23$ & 38 & 32.7 & 24.2 & 90 & 66 & 076.6 & 03.6 & 5.9 & 27.19 \\
\hline Sept & $24-30$ & 39 & 32.6 & 23.2 & 87 & 62 & 003.4 & 02.9 & 8.9 & 19.13 \\
\hline \multicolumn{3}{|c|}{ Correlation shoot infestation (\%) } & $0.351^{\mathrm{NS}}$ & $0.149^{\mathrm{NS}}$ & $0.784^{\mathrm{NS}}$ & $0.661^{\mathrm{NS}}$ & $0.691^{\mathrm{NS}}$ & $0.253^{\mathrm{Ns}}$ & $-0.902^{*}$ & \\
\hline
\end{tabular}

* Significant at 0.01 level; ** Significant at 0.05 level, Max - Maximum temperature, Min. - Minimum temperature

\section{References}

1. Anonymous. Ministry of Agriculture, Government of India, Indian Horticulture Database, 2018.

2. Aziz MA, Hasan M, Ali A. Impact of Abiotic Factors on Incidence of Fruit and Shoot Infestation of Spotted Bollworms Earias spp. on Okra (Abelmoschus esculentus L.). Pakistan Journal of Zoology. 2011; 43(5):863-868.

3. Bajjad VV, Singh HP, Patil SC. Efficacy of chemical insecticides against shoot and fruit borer, Earias vittella (Fab.) on okra. Trends in biosciences. 2014; 7(14):1644646.

4. Dhamdhere SV, Bahadur I, Mishra US. Studies on occurrence and succession of pests of okra at Gwalior. Indian Journal of Plant protection. 1984; 12:9-12.

5. Hiremath IG, Thontadarya TS. Estimation of damage due to cotton spotted bollworm. current research, University of Agriculture Sciences, Bangalore. 1984; 13(7):55-56

6. Lal H, Mahal MS, Singh R, Singh B. Influence of rainfall on population build-up of Amrasca biguttula biguttula (Ishida) on 'Okra'. J Insect Sci. 1990; 3:169-171.

7. Laichattiwar MA, Meena RS, Singh PS, Yadav NK. Seasonal incidence of shoot and fruit borer (Earias vitella) of okra (Abelmoschus esculentus) in the Gangetic plains of Uttar Pradesh. Current Advances in Agricultural Sciences. 2014; 6(2):205-206.

8. Kadam JR, Khaire VM. Raining and relative humidity: key factors to suppress Earias vitella (Fabricius) infestation on okra crop. Journal of Entomological Research. 1995; 19(3):201-205.

9. Karmakar P. Studies on interspecific hybridization in brinjal, Solanum melongena L. M.Sc. Thesis, GBPUAT, Pantnagar.

10. Krishnaiah K. Methodology for assessing crop losses due to pests of vegetable. Assessment of crop losses due to pests and diseases. Proceeding of workshops, 1980, 259267.

11. Meena NK, Kanwat PM, Meena A, Sharma JK. Seasonal incidence of jassids and whiteflies on okra, Abelmoschus esculentus (L.) Moench in semi-arid region of Rajasthan. Annals of Agri Bio Research. 2010; 15(1):25-29
12. Padwal, Kanchan G, Sujeet K. Sharma. Population Dynamics of Earias vittella of Okra. Annals of Plant Protection Sciences. 2015; 23(2):398-399

13. Peirce LC. Vegetables: Characteristics, Production and Marketing. Jphn Wiley and Sons, Canada, 1987, 399401p.

14. Radke SG, Undirwade RS. Seasonal abundance and insecticidal control of shoot and fruit borer, Earias spp.on okra, Abelmoschus esculentus (L.) Moench Thesis, Udaipur Univesity, Rajasthan, 1981.

15. Rawat RR, Sahu HR. Estimation of losses in growth and yield of okra due to Emposca devastans and Earias sp. Indian Journal of Entomology. 1973; 35:252-254.

16. Sharma RP, Swaminatha, Bhati KK. Seasonal incidence of fruit and shoot borerof okra along with climatic factors in Udaipur region of India. Asian journal of agricultural research. 2010; 4(4):232-236.

17. Sardana HR, Kumar NK. Effectiveness of plant oils against leafhopper and shoot and fruit borer on okra. Indian Journal of Entomology. 1989; 51(2):167-171.

18. Singh H, Kumar A. Efficacy and Economic of Biopesticides for Management of Fruit Borers in Okra Annals of Plant Protection Sciences, 2009, 17(2).

19. Srinivasan K, Kishnakumar NK, Ramchander PR, Rao GSP. Seasonal patterns of leafhopper, Amrasca biguttula biguttula on okra in India. International Journal of Tropical Insect Science. 1988; 9(1):85-88.

20. Tripathi SR, Singh AK. Effect of food plants on development, growth and reproduction of Earias vittella (Fabr.). Indian Jounal of ecology. 1990; 17(1):83-85

21. Yadvendu TC. Evaluation of newer insecticides against insect pest of okra [Abelmoschus esculentus (L.) Moench]. Msc. Thesis, Maharana Pratap University of Agriculture and Technology, Udaipur, Rajasthan, 2001. 